Research Article

\title{
Variability in the Extreme Precipitation on the Chuandian Plateau, China
}

\author{
Li Zhou ${ }^{1,2} \cdot$ Xuebiao Pan $^{2} \cdot$ Qi Hu $\cdot$ Hua Xu ${ }^{3}$
}

Received: 12 April 2019 / Accepted: 25 October 2019 / Published online: 1 November 2019

(c) Springer Nature Switzerland AG 2019

\begin{abstract}
Extreme precipitation events can cause disasters, especially in areas with complex terrain. It is very important to identify whether the spatiotemporal distribution of extreme precipitation intensity over the Chuandian Plateau of China has changed. This paper selects five indices from the Expert Team on Climate Change Detection Indices that can reflect the extreme precipitation intensity. $K$-means clustering results in two distinct precipitation seasons. The spatial distribution and trends of precipitation are analyzed using daily quality-controlled data series from 20 meteorological stations from 1971 to 2015. The main results are as follows: (1) The extreme precipitation intensity increases from the north to the south of the region, with high-value areas in the southwestern and southeastern areas and low-value areas in the western and eastern areas. (2) The extreme precipitation intensity is higher, and the spatial differences are smaller during the wet season than during the dry season. The spatial variabilities in June and July are greater than those in August and September. The largest contributors to annual rainfall are the wet season and July. (3) The extreme precipitation intensity shows an increasing trend, especially in the central areas, even though the majority of the trends are not statistically significant. (4) The intensity of the extreme precipitation exhibits a relatively strong trend during the wet season and July, which could result in serious geomorphological disasters. It is critical to detect the characteristics and trends of extreme precipitation intensity-related disasters and develop appropriate adaptation and mitigation strategies.
\end{abstract}

Keywords Extreme precipitation index $\cdot$ Spatiotemporal distribution · Intensity $\cdot K$-means clustering method · Chuandian Plateau . China

\section{Introduction}

In many regions of the world, extreme precipitation is one of the most important climate variables [1], and precipitation has a substantial influence on natural and social environments, including various disasters. According to the Intergovernmental Panel on Climate Change [2, 3], extreme precipitation events will continue to increase in number and intensity due to climate change and human activities. For example, during the period from 2000 to 2016, a total of 2790 flood disasters were reported globally in the International Emergency Disasters Database (EM-DAT), which is much more than the 1807 flood disasters that were reported from 1960 to 1999 . Obviously, in regions with complex terrain, extreme precipitation intensity can lead to more geomorphological disasters, such as mountain flooding, soil and water losses, landslides and mudslides. Therefore, there is an important and

Electronic supplementary material The online version of this article (https://doi.org/10.1007/s42452-019-1577-y) contains supplementary material, which is available to authorized users.

Xuebiao Pan, yumeng9949@sohu.com | ${ }^{1}$ College of Geography and Resources Science, Neijiang Normal University, Sichuan 641112, Neijiang, China. ${ }^{2}$ College of Resources and Environmental Sciences, China Agricultural University, Beijing 100193 , China. ${ }^{3}$ Zizhong County Bureau of Meteorology, Sichuan 641200, Neijiang, China. 
urgent need to assess the spatial distributions and trends of extreme precipitation events.

Extreme precipitation events have attracted increasing interest in the scientific community. Substantial evidence has indicated that the increasing trends of extreme precipitation events over the past several decades have been detected over most areas in warmer climates [4]. However, the spatial patterns of extreme precipitation differ from one region to another throughout the world [5]. Previous research has shown that extreme precipitation is highly sensitive to climate warming, especially in mountain and highland regions [6], and this trend is most obvious in the southwestern region of China, where extreme precipitation events are common [7].

The Chuandian Plateau is located in southwest China, at $98^{\circ} 08^{\prime}-104^{\circ} 58^{\prime} \mathrm{E}, 26^{\circ} 28^{\prime}-34^{\circ} 19^{\prime} \mathrm{N}$. The Chuandian Plateau has complex topography, and plateau and alpine valleys are the main landforms of the region, which includes three areas: the Songpan Plateau, the Western Sichuan Plateau and the Hengduan Mountains (Fig. 1). In the southern region, the north-south mountains and valleys are aligned from the west to the east [8]. Comparatively, most rivers also run north to south. The mountains obstruct the East Asian Monsoon (EAM) in the west-east direction and provide a thoroughfare for the South Asian Monsoon (SAM) in the south-north direction [9]. The Western Sichuan Plateau and Songpan Plateau are located in the central and northern regions, respectively. The Chuandian Plateau is affected by complex seasonal monsoons, such as the SAM from the Indian Ocean and Bay of Bengal, the southern branch of the westerlies, the local climate of the Tibetan Plateau [10] and the EAM. Among them, the energy driving the EAM and SAM results from the thermal contrast between the Asian landmass and surrounding seas. This significantly impacts patterns of continental temperature and precipitation $[11,12]$. The Pacific Decadal Oscillation (PDO), defined by the leading empirical orthogonal function of Pacific sea surface temperature (SST) north of $20^{\circ} \mathrm{N}$ after removing global SST [13], has been documented to alter the EAM directly and through its response to ENSO. Generally, the Chuandian Plateau is the main transition zone from the terrain of the Tibetan Plateau to the Yunnan-Guizhou Plateau and the Sichuan Basin, which is the main area of landslides, mountain floods and mudslides in China. However, extreme precipitation plays a major role in these geomorphological disasters.

To date, few studies have intensively discussed the extreme precipitation events in some regions associated with the Chuandian Plateau of China, such as the southwest of China [14-16], Sichuan Province [17-19], and Yunnan Province [20]. Although previous studies have included the area, very little attention has been paid to
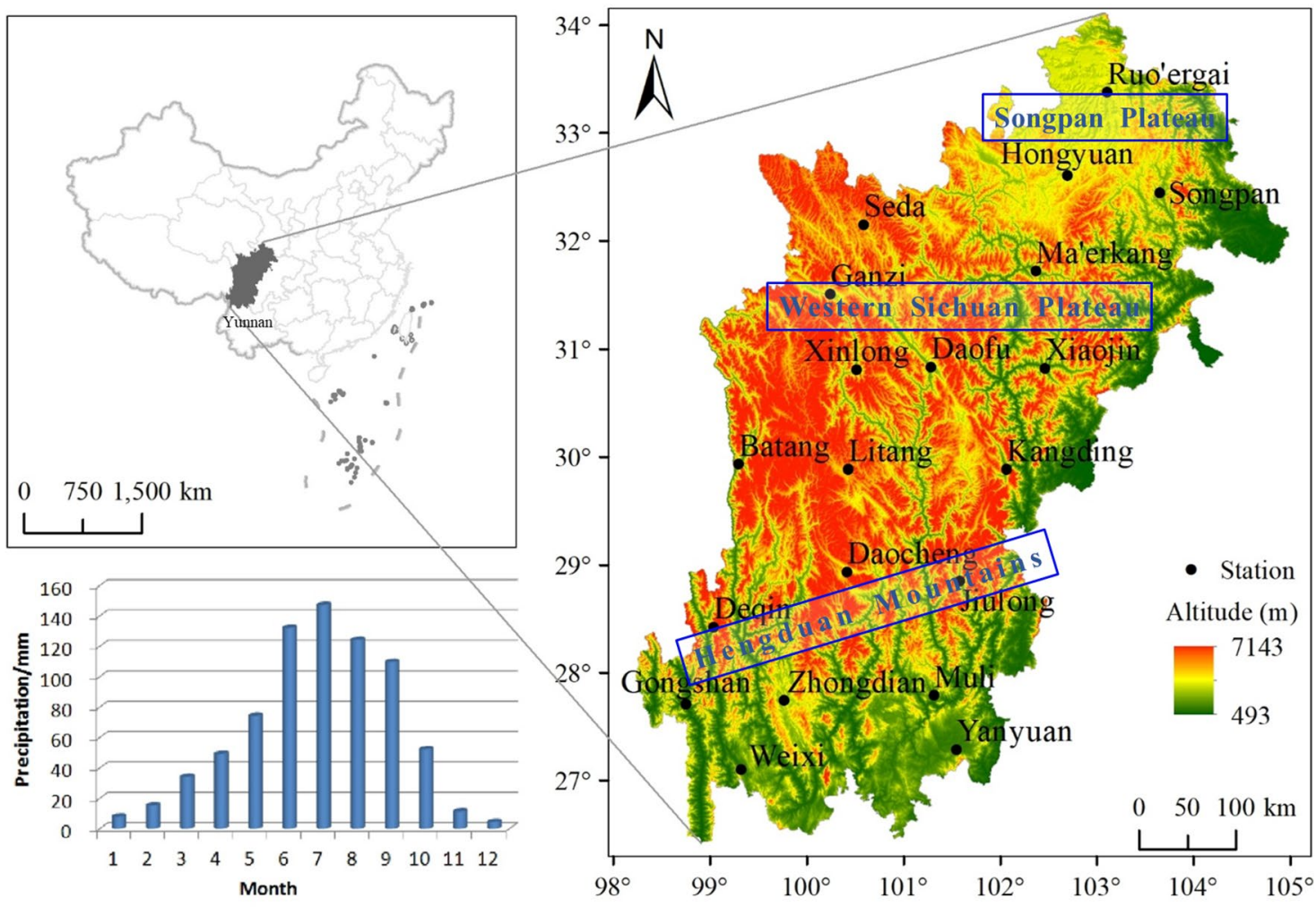

Fig. 1 Locations of the meteorological stations on the Chuandian Plateau of China. Annual precipitation from 1971 to 2015 
the Chuandian Plateau of China, while many studies have focused on the agropastoral ecotone of northern China $[21,22]$. Consequently, we need to provide sufficient information on the spatiotemporal variability and trends of the extreme precipitation intensity over the study region. Such information is critical for understanding disasters related to extreme precipitation intensity and developing appropriate adaptation and mitigation strategies.

This study aims to determine the spatiotemporal changes in the extreme precipitation intensity. The main goal is to determine the changes in the annual, seasonal and monthly extreme precipitation intensities using a set of 5 intensity indices generated by the joint CCI/CLIVAR/ JCOMM Expert Team on Climate Change Detection and Indices (ETCCDI) (http://etccdi.pacificclimate.org/), which is a widely used approach.

\section{Materials and methods}

\subsection{Extreme precipitation intensity indices}

There are a variety of definitions for extreme precipitation [23]. Here, we select five extreme precipitation indices recommended by the ETCCDI (http://etccdi.pacificclimate. org/) to characterize the annual, seasonal and monthly extreme precipitation events. These precipitation indices address precipitation depth or intensity, and they are the PRCPTOT, SDII, RX1 day, RX5 day and R95pTOT. In this way, we can gain better insight into the often subtle or hidden features of the major climatic regions of the Chuandian Plateau of China [24].

PRCPTOT, which reflects the total precipitation in days with daily precipitation values $\geq 1 \mathrm{~mm}$ during certain time periods, is probably the most important index that reflects variations in precipitation. SDIl accounts for the daily mean precipitation during wet days. RX1 day and RX5 day account for the monthly maximum 1-day and consecutive 5 -day precipitation during certain time periods, respectively. R95pTOT is an index for measuring heavy precipitation that exceeds the 95th percentile threshold, which is derived from precipitation on wet days from 1971 to 2015. Detailed descriptions are provided in Table 1. Daily precipitation data from 20 meteorological stations (Table 2) covering the Chuandian Plateau are provided by the National Climate Center of the China Meteorological Administration (http://data. $\mathrm{cma} . \mathrm{cn} /$ ). RClimDex software (which is developed and maintained by the Climate Research Department of the Canadian Meteorological Agency, http://etccdi.pacificcli mate.org/software.shtml) and Excel software are used to calculate the indices from the daily data after data quality control [23]. We assume that the chosen indices provide a good measure of intensity.

Table 2 List of meteorological stations, their World Meteorological Organization (WMO) number, latitude, longitude and altitude (m)

\begin{tabular}{lllll}
\hline $\begin{array}{l}\text { Station } \\
\text { name }\end{array}$ & WMO no. & Latitude $\left({ }^{\circ} \mathrm{N}\right)$ & $\begin{array}{l}\text { Longitude } \\
\left({ }^{\circ} \mathrm{E}\right)\end{array}$ & Altitude $(\mathrm{m})$ \\
\hline Ruo'ergai & 56079 & 33.58 & 102.97 & 3439.6 \\
Ganzi & 56146 & 31.62 & 100.00 & 3393.5 \\
Seda & 56152 & 32.28 & 100.33 & 3893.9 \\
Daofu & 56167 & 30.98 & 101.12 & 2957.2 \\
Ma'erkang & 56172 & 31.90 & 102.23 & 2664.4 \\
Hongyuan & 56173 & 32.80 & 102.55 & 3491.6 \\
Xiaojin & 56178 & 31.00 & 102.35 & 2369.2 \\
Songpan & 56182 & 32.65 & 103.57 & 2850.7 \\
Batang & 56247 & 30.00 & 99.10 & 2589.2 \\
Xinlong & 56251 & 30.93 & 100.32 & 3000.0 \\
Litang & 56257 & 30.00 & 100.27 & 3948.9 \\
Daocheng & 56357 & 29.05 & 100.30 & 3727.7 \\
Kangding & 56374 & 30.05 & 101.97 & 2615.7 \\
Deqin & 56444 & 28.48 & 98.92 & 3319.0 \\
Muli & 56459 & 27.93 & 101.27 & 2426.5 \\
Jiulong & 56462 & 29.00 & 101.50 & 2987.3 \\
Gongshan & 56533 & 27.75 & 98.67 & 1583.3 \\
Zhongdian & 56543 & 27.83 & 99.70 & 3276.1 \\
Weixi & 56548 & 27.17 & 99.28 & 2326.1 \\
Yanyuan & 56565 & 27.43 & 101.52 & 2545.0 \\
\hline & & & &
\end{tabular}

Table 1 Extreme precipitation indices used in this study

\begin{tabular}{|c|c|c|}
\hline Index & Description & Formula \\
\hline PRCPTOT $(\mathrm{mm})$ & Total wet-day precipitation & Total precipitation on wet days ( $R R \geq 1 \mathrm{~mm}$ ) \\
\hline SDII (mm/day) & Simple daily intensity index & Total precipitation divided by the number of wet days $(R R \geq 1) \mathrm{mm}$ ) \\
\hline $\mathrm{RX} 1$ day $(\mathrm{mm})$ & $\begin{array}{l}\text { Highest precipitation amount in a one- } \\
\text { day period }\end{array}$ & Maximum precipitation in 1-day intervals \\
\hline RX5 day $(\mathrm{mm})$ & $\begin{array}{l}\text { Highest precipitation amount over } 5 \\
\text { consecutive days }\end{array}$ & Total maximum precipitation over 5-day intervals \\
\hline R95pTOT (mm) & Very wet days & Precipitation amounts due to very wet days (>95th percentile) \\
\hline
\end{tabular}




\subsection{K-means clustering}

Cluster analysis is a multivariate statistical method for quantitative research classification that classifies samples without classified information according to the degree of similarity between samples. $K$-means clustering is a type of cluster analysis method that was proposed by Mac Queen in 1967. K-means clustering is suitable for rapidly clustering large samples. When we know how many classes to group the data into, the use of $K$-means clustering saves computing time. The idea behind $K$-means clustering is to form the initial classification. First, we use a specific method to select a number of cluster centers. The cluster centers ensure that the samples are grouped close together. Then, according to the nearest distance principle, these centers are continuously modified until the unreasonable classifications become reasonable [25]. In this study, K-means clustering, performed using the SPSS software, is used to divide the dry season and wet season.

\subsection{Trend calculation}

The annual, seasonal and monthly trends of the climate indices are calculated by a high-dimensional linear regression method. This procedure is implemented in the Excel software, and the slopes, as well as their statistical significance, are provided as outputs of the analysis. The detailed calculation process can be found in Hu et al. [26]. We use two statistical significance levels in this paper because the statistical significance of precipitation trends is usually lower than that of other climate elements due to the large spatial and temporal variability in precipitation [27]. We consider the statistical significance levels $\leq 0.05$ 'strongly significant changes' and values between 0.05 and 0.1 'significant changes'.

\subsection{Coefficient of variation}

The spatial difference in the extreme precipitation intensity can be expressed statistically by the coefficient of variation (CV), which can measure the degree of spatial difference in the same index [28]. The greater the CV is, the greater the spatial difference is [29].

The calculation formula is as follows:

$\mathrm{CV}=\frac{1}{\bar{x}} \sqrt{\frac{1}{(n-1)} \sum_{i=1}^{n}\left(x_{i}-\bar{x}\right)^{2}}$

In the formula, CV is the coefficient of variation, $i$ is the sequence of the meteorological stations, $x_{i}$ is the extreme precipitation intensity index of the ith meteorological station, and $\bar{x}$ is the average value of the extreme precipitation intensity indices of each meteorological station.

\section{Results}

\subsection{Annual extreme precipitation intensity analysis}

\subsubsection{Spatial characteristics}

The spatial distributions of the PRCPTOT, SDII, RX1 day, RX5 day and R95PTOT indices over the Chuandian Plateau are shown in Fig. 2. Over the period from 1971-2015, the annual extreme precipitation intensity indices generally increase from the north to the southwest and southeast, with values ranging from 456.6 to $1707.6 \mathrm{~mm}, 6.1$ to $10.3 \mathrm{~mm}, 27.6$ to $68.8 \mathrm{~mm}, 56.5$ to $169.5 \mathrm{~mm}$ and 87.4 to $385.2 \mathrm{~mm}$. Every index of the annual extreme precipitation intensity shows a trend of decreasing from the southwest to the northeast and from the south to the north. This may be a reflection of the fact that the longitudinal ridge valley acts as both an east-west barrier and a north-south channel to the EAM and SAM flowing through the region [30]. By comparing the coefficient of variation (CV) of each index, it is found that R95PTOT has the largest spatial difference, with a CV of $40.08 \%$, followed by PRCPTOT, with a CV of $33.25 \%$. SDII has the smallest spatial difference, with a CV of $16.10 \%$.

\subsubsection{Trends}

The annual PRCPTOT on the Chuandian Plateau has increased by approximately $19.08 \mathrm{~mm}$ over the last 45 years, with an average trend of $4.24 \mathrm{~mm}$ per decade. On the Chuandian Plateau, SDII increases slightly (by $0.41 \mathrm{~mm}$ ) over the period from 1971 to 2015, with an average trend of $0.09 \mathrm{~mm}$ decade $^{-1}$, and $90 \%$ of the stations show positive trends for SDII. RX1 day and R95PTOT increase on the Chuandian Plateau with trends of $0.25 \mathrm{~mm}$ decade $^{-1}$ and $4.29 \mathrm{~mm}$ decade $^{-1}$, respectively. However, RX5 day decreases on the Chuandian Plateau, with a trend of $-0.05 \mathrm{~mm}$ decade ${ }^{-1}$. In addition, for the above five indices, only $5-15 \%$ of the stations show significant trends. The spatial distributions of the climatic trend rates for PRCPTOT, SDII, RX1 day, RX5 day and R95pTOT are shown in Fig. 3. The trends for both PRCPTOT and RX5 day decrease from the center to the north and south. The largest increases in PRCPTOT and RX5 day occur at the Litang station, which is in the center of the region, with trends greater than $32.41 \mathrm{~mm}$ decade $^{-1}$ and $4.9 \mathrm{~mm}^{\text {decade }}{ }^{-1}$, respectively (Fig. 3a, d). The central area shows positive trends. In contrast, most of the areas in the south and north show negative trends for PRCPTOT and RX5 day. SDII, RX1 day and 


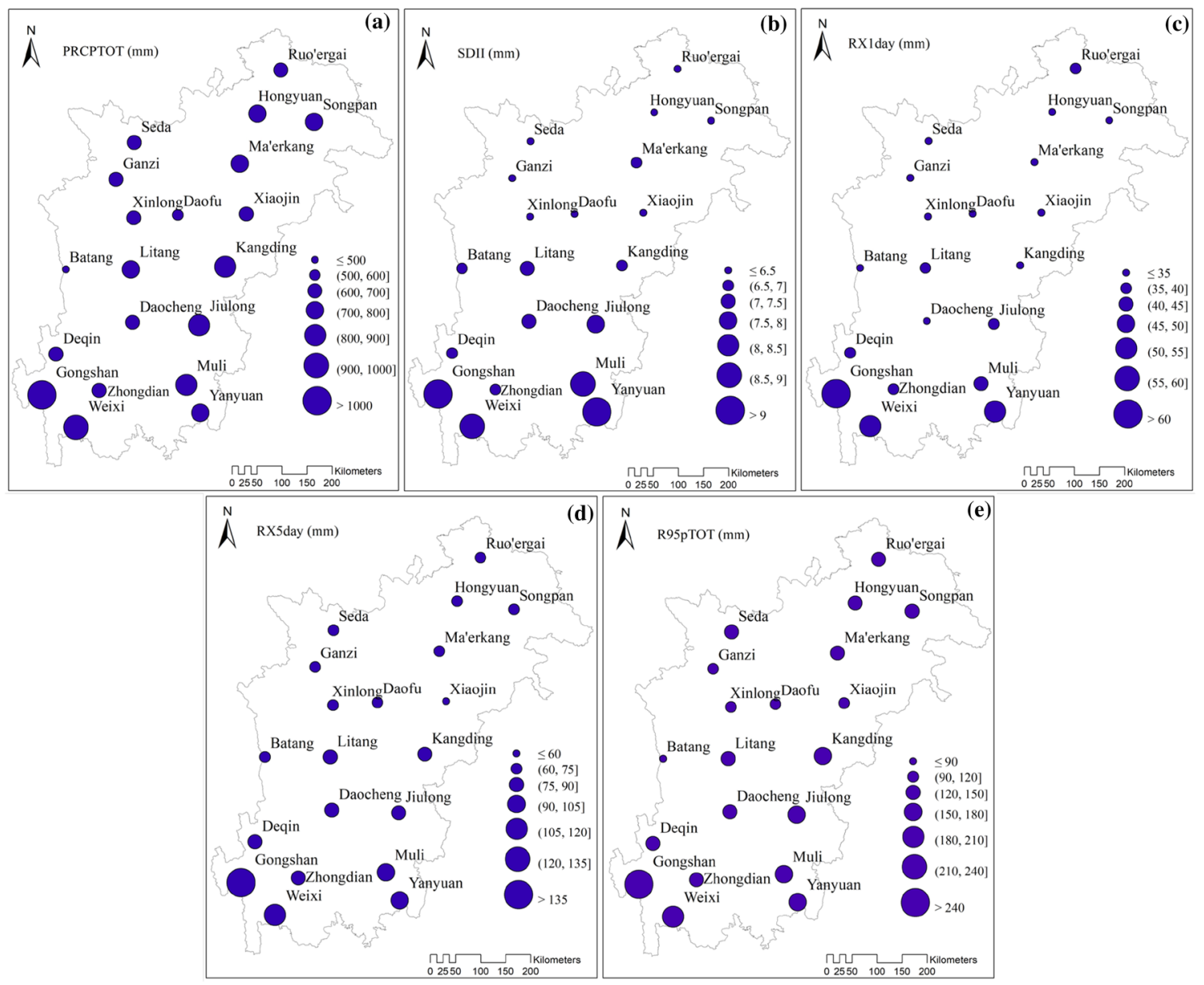

Fig. 2 Annual spatial characteristics of the extreme precipitation intensity over the Chuandian Plateau from 1971 to 2015

R95pTOT increase faster at the Muli station in the southeastern area than in the other areas, with trends greater than $0.4 \mathrm{~mm}$ decade $^{-1}, 3.3 \mathrm{~mm}$ decade $^{-1}$ and $22.32 \mathrm{~mm}$ decade $^{-1}$, respectively. The Gongshan station, which is in the southwestern area, shows the largest decreases in SDII, RX1 day and R95pTOT with trends less than $-0.1 \mathrm{~mm}$ decade $^{-1},-2.8 \mathrm{~mm}$ decade $^{-1}$ and $-20.55 \mathrm{~mm}$ decade $^{-1}$, respectively, as shown in Fig. 3b, c, e. The SDII and R95PTOT trends for the whole region are significant at the 0.05 and 0.1 levels, respectively (Table 3 ). One common feature of all the indices is that the southwestern area shows the most pronounced decrease in the study area. From May to September, the southwest monsoon (the south Asian summer monsoon, SASM) prevails [31-33]. However, studies have confirmed that the Asian monsoon (including the EAM and SAM) circulation intensity appears to have been obviously reduced for nearly half a century, especially since the 1970s [34, 35]. In recent years, some scholars have speculated about the variation in the SASM by measuring the $\delta^{18} \mathrm{O}$ content in stalagmites, and the results show that the SASM has had a weakening trend for almost half a century [36, 37]; it is proposed that the SASM weakening could be the main reason for the decrease in precipitation in the southwestern area of the Chuandian plateau over the past 45 years.

\subsection{Seasonal extreme precipitation intensity analysis}

This paper considers the average monthly precipitation data for each meteorological station in the region from 1971 to 2015 as a variable with which to divide the twelve months into two categories. Among the stations, 19 meteorological stations have the same patterns, including cluster 1 (January to May, October to December) and cluster 2 (June to September) (Fig. 4a). Only the Gongshan meteorological station has a different pattern in cluster 1 (January, November, December) and cluster 2 (February to October) (Fig. 4b). The above categories identified by the $K$-means clustering analysis were all significant at the 0.05 level; thus, this method 


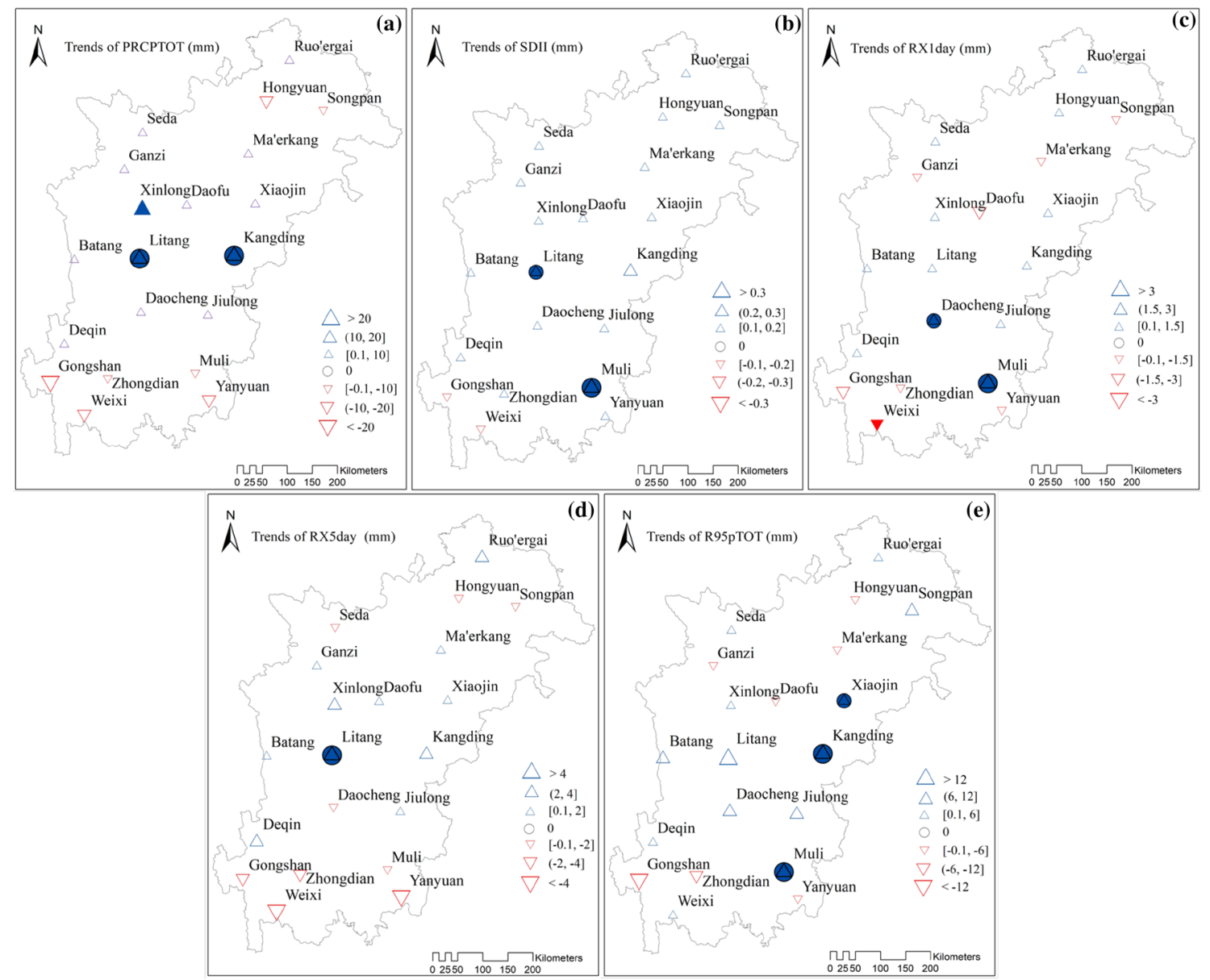

Fig. 3 Annual linear trends (per decade) of the extreme precipitation intensity over the Chuandian Plateau from 1971 to 2015 (The sizes of the triangles are proportional to the trend values: larger triangles correspond to larger values of the linear trends. Filled triangles indicate significant trends at the 0.1 level. Filled triangles within circles indicate strongly significant trends at the 0.05 level. The following figures have the same meaning)
Table 3 Average trends of the extreme precipitation intensity $\left(\mathrm{mm} \mathrm{decade}^{-1}\right)$ and the significant trends for all the stations on the Chuandian Plateau except the Gongshan station (the annual indices include the Gongshan station)

\begin{tabular}{lcclcllr}
\hline Indices & Annual & Dry season & Wet season & June & July & August & September \\
\hline PRCPTOT & 4.24 & 2.72 & 3.89 & 1.65 & 0.77 & 4.95 & $-3.47^{*}$ \\
SDII & $0.09^{* *}$ & 0.07 & $0.13^{* *}$ & 0.11 & $0.18^{* *}$ & $0.22^{* *}$ & 0.04 \\
RX1 day & 0.26 & 0.18 & $0.62^{* *}$ & 0.24 & $0.59^{* *}$ & $0.81^{* *}$ & -0.05 \\
RX5 day & -0.04 & 0.07 & 0.49 & -0.48 & 0.96 & 0.55 & -0.07 \\
R95pTOT & $4.29^{*}$ & -0.27 & $5.87^{* *}$ & 1.65 & $2.32^{*}$ & 1.79 & 0.08 \\
\hline
\end{tabular}

${ }^{*}$ At level $a=0.1,{ }^{* *}$ At level $a=0.05$ generated appropriate clustering results. According to the average monthly precipitation data, cluster 1 represents the dry season, and cluster 2 represents the wet season. The seasonal precipitation that occurs during the wet season represents $70.48 \%$ and $92.06 \%$ of the total annual precipitation for the 19 meteorological stations and the Gongshan meteorological station, respectively. The Gongshan meteorological station will be analyzed separately.
The Gongshan station does not conform with the dry and wet season division patterns of the other stations. Thus, the analysis of the seasonal extreme precipitation intensity in this study does not consider the Gongshan station. The spatial distributions of the seasonal PRCPTOT, SDII, RX1 day, RX5 day and R95pTOT indices on the Chuandian Plateau are shown in Fig. 5. Over the period from 1971 to 2015 , the wet seasonal extreme precipitation intensity indices generally decreased from the southeast to the 
Fig. 4 Division of the dry and wet seasons. a The entire research region except for the Gongshan meteorological station; $\mathbf{b}$ the Gongshan meteorological station
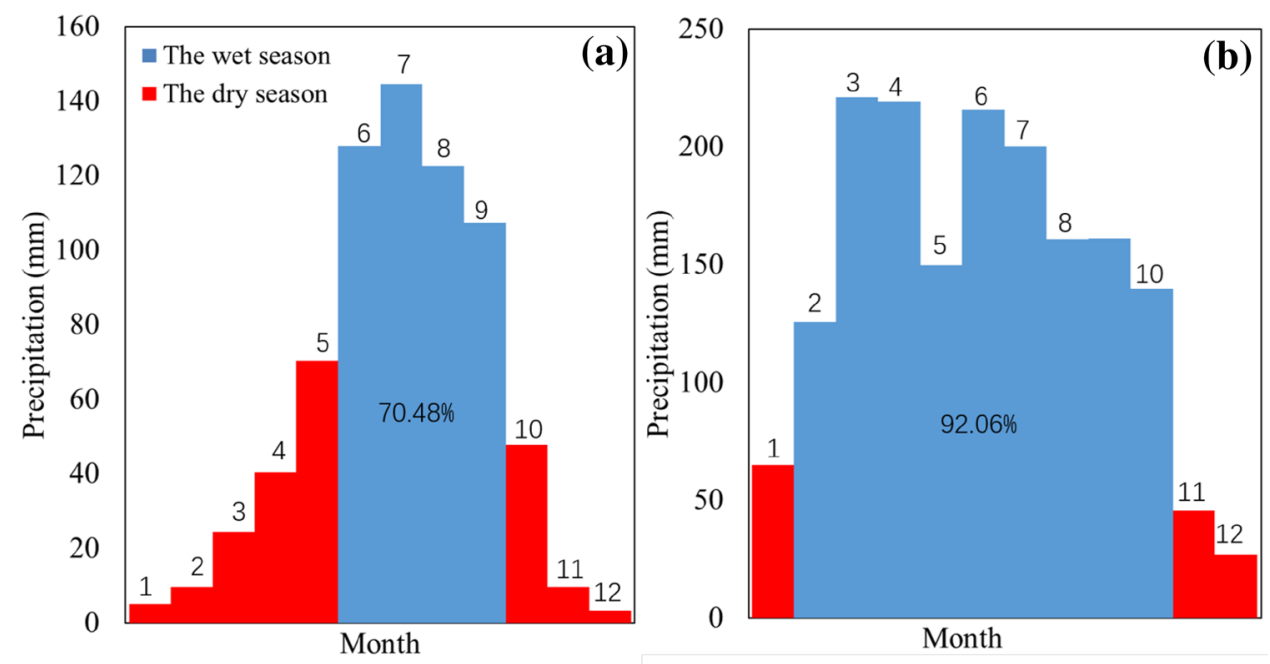

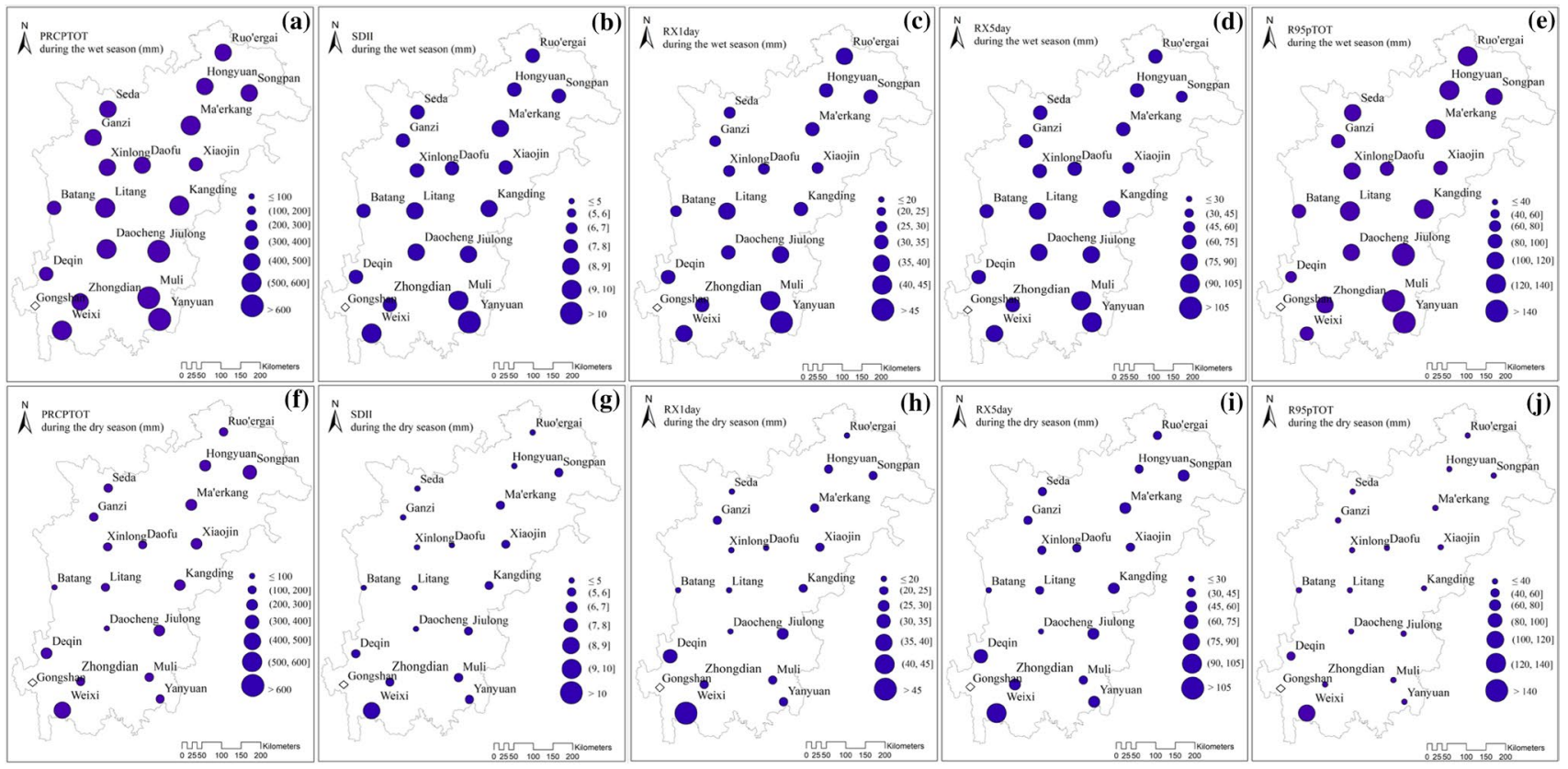

Fig. 5 Seasonal spatial characteristics of the extreme precipitation intensity over the Chuandian Plateau from 1971 to 2015 (diamond means that the Gongshan station is not included in the statistical range, and the following figures have the same meaning)

other areas, with values ranging from 358.4 to $675.5 \mathrm{~mm}$, 7.2 to $10.5 \mathrm{~mm}, 27.0$ to $50.7 \mathrm{~mm}, 55.8$ to $95.1 \mathrm{~mm}$ and 76.1 to $165.4 \mathrm{~mm}$ (Fig. 5a-e). The lowest PRCPTOT and R95pTOT values are observed at the Deqin station, and the lowest SDII and RX1 day values are observed at the Ganzi station. Both stations are located in the western part of the region. However, the lowest RX5 day value is at the Xiaojin station, which is in the eastern part of the region. In contrast, the highest values of all the indices are observed at the Jiulong station, Yanyuan station and Muli station, which are in the southeastern part of the region. With the largest spatial difference, R95pTOT has a CV of $21.51 \%$, followed by PRCPTOT and RX1 day, with CVs of $18.27 \%$ and $17.37 \%$, respectively. SDII has the smallest spatial difference (11.31\%). Moreover, the extreme precipitation intensity during the wet season makes a very large contribution to the annual extreme precipitation intensity, i.e., the average PRCPTOT, SDII, RX1 day, RX5 day and R95PTOT values in the wet season are $71.2 \%, 114.7 \%, 96.2 \%, 96.7 \%$ and $83.6 \%$, respectively.

However, the spatial distribution of the extreme precipitation intensity indices during the dry season decreases from the southwest to the other areas, with values ranging from 77.0 to $422.6 \mathrm{~mm}, 3.8$ to $8.7 \mathrm{~mm}, 14.4$ to $45.5 \mathrm{~mm}$, 
27.2 to $96.2 \mathrm{~mm}$ and 5.0 to $105.2 \mathrm{~mm}$ (Fig. $5 \mathrm{f}-\mathrm{j}$ ). The lowest PRCPTOT, RX1 day and RX5 day values are observed at the Batang station, and the lowest SDII and R95PTOT values are observed at the Seda station and Daocheng station, respectively. The above three stations are located in the western part of the region. In contrast, the highest values of all the indices are observed at the Weixi station. This station is in the southwestern part of the region. R95pTOT shows the greatest spatial difference, with a CV of $94.32 \%$, followed by PRCPTOT, which has a CV of $41.33 \%$. SDII has the smallest spatial difference (20.41\%). Compared with the wet season, the extreme precipitation intensity indices of the dry season have a larger range, larger spatial differentiation and smaller average value.

The wet season PRCPTOT on the Chuandian Plateau has increased by approximately $17.51 \mathrm{~mm}$ over the last 45 years, with an average trend value of $3.89 \mathrm{~mm} \mathrm{decade}^{-1}$. R95PTOT on the Chuandian Plateau increases by $26.42 \mathrm{~mm}$ over the period from 1971 to 2015, with an average trend value of $5.87 \mathrm{~mm}^{\text {decade }}{ }^{-1}$. SDII, RX1 day and RX5 day also show slightly positive trends of $0.13 \mathrm{~mm}$ decade $^{-1}$, $0.62 \mathrm{~mm}$ decade $^{-1}$ and $0.49 \mathrm{~mm}$ decade ${ }^{-1}$, respectively. In addition, for the above five indices, less than $21.05 \%$ of the stations show a significant trend. The spatial distributions of the climatic trends of PRCPTOT, SDII, RX1 day, RX5 day and R95pTOT are shown in Fig. 6a-e. Both the PRCPTOT and RX5 day trends decrease from the center to the north and south. The largest increases in PRCPTOT and RX5 day occur at the Litang station, which is located in the center of the region, with trends greater than $24.02 \mathrm{~mm}$ decade $^{-1}$ and $5.6 \mathrm{~mm}$ decade ${ }^{-1}$, respectively. The central area shows positive trend values. In contrast, most of the areas in the south and north show negative trends for PRCPTOT and RX5 day. SDII, RX1 day and R95pTOT increase faster at the Muli station in the southeastern area than they do in the other areas, with trends greater than $0.5 \mathrm{~mm}$ decade ${ }^{-1}$, $3.3 \mathrm{~mm}$ decade ${ }^{-1}$ and $20.49 \mathrm{~mm}^{\text {decade }}{ }^{-1}$, respectively. The Yanyuan station, which is also in the southeastern area, shows the largest decreases in SDII, RX1 day and RX5 day, with trends less than $-0.1 \mathrm{~mm}^{\text {decade }}{ }^{-1}$, $-1.1 \mathrm{~mm}$ decade $^{-1}$ and $-4.7 \mathrm{~mm}$ decade $^{-1}$, respectively. The climatic trends of the extreme precipitation intensity indices during the wet season are all higher than those for the entire year, except for PRCPTOT. For the whole region, the SDII, RX1 day and R95pTOT indices during the wet season are significant at the 0.05 level (Table 3 ).

The climatic trends of the extreme precipitation intensity indices during the dry season are all smaller than those during the wet season, i.e., the average PRCPTOT, SDII, RX1 day, RX5 day and R95PTOT values during the dry season are $2.72 \mathrm{~mm}$ decade $^{-1}, 0.07 \mathrm{~mm}$ decade $^{-1}, 0.18 \mathrm{~mm}$ decade $^{-1}, 0.07 \mathrm{~mm}$ decade ${ }^{-1}$ and $-0.27 \mathrm{~mm}_{\text {decade }}{ }^{-1}$, respectively. None of them passed the significance test (Table 3). In particular, R95pTOT exhibits the largest difference between the dry and wet seasons (Fig. 6e, j). This should indicate an increasingly uneven distribution of the extreme precipitation intensity between the wet season and dry season. This also indicates that the strength of the SASM and EASM (East Asian summer monsoon) tends to concentrate more toward the wet season. For the above

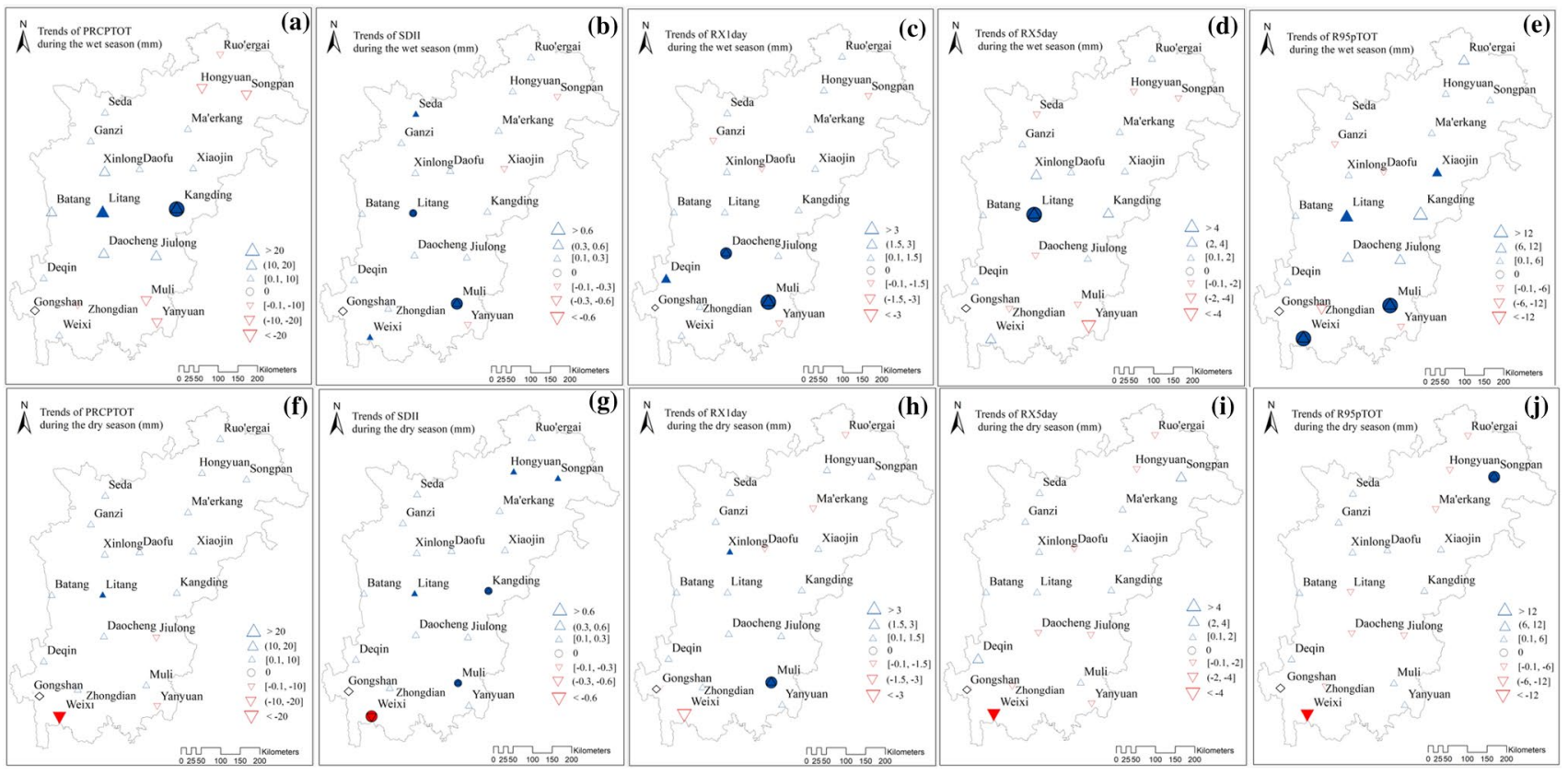

Fig. 6 Seasonal linear trends (per decade) of extreme precipitation intensity over the Chuandian Plateau from 1971 to 2015 
five indices, the largest increases in SDII and RX1 day occur at the Muli station, which is in the southeastern area, and the largest increases in PRCPTOT, RX5 day and R95pTOT occur at the Ma'erkang station and the Songpan station, which are in the northern area. However, the largest decreases occur at the Weixi station in the southwest, which represents the highest value of all the indices in the dry season (Fig. $6 f-j$ ).

\subsection{Monthly extreme precipitation intensity analysis}

\subsubsection{PRCPTOT index}

PRCPTOT is calculated for each month. The results indicate that the monthly PRCPTOT generally increases from north to south and from west to east in this region (Fig. 7a-d). It is affected by monsoons coming from both directions. The largest spatial differences in PRCPTOT typically occur in June (Fig. $7 \mathrm{a}$ ), when the CV is $27.28 \%$. The PRCPTOT index is less than $200 \mathrm{~mm}$ for all stations in the analyzed territory except for the Muli and Yanyuan stations, which are in the southeastern area. The minimum PRCPTOT values are typically found at the Deqin station, which is in the southwestern area, and the Xiaojin station, which is in the eastern area. A large gradient in PRCPTOT exists in the southern areas. The main reasons for this are that the elevation difference between the stations in the southern region is large, and the southern region is the first area where the two monsoons arrive. July is characterized by the greatest average PRCPTOT value $(142.6 \mathrm{~mm})$ and a nonuniform distribution with a CV of $25.02 \%$. (Figure $7 \mathrm{~b}$ ). The values of PRCPTOT are higher than the average values in the southern areas. After July, the average values of PRCPTOT decrease: the values for August and September are $120.5 \mathrm{~mm}$ and $105.3 \mathrm{~mm}$, respectively. Moreover, the CV decreases successively from June to September.

In June and July, the linear trends of PRCPTOT are positive for the center of the Chuandian Plateau, but there are almost as many negative trends in the northern and southern areas (Fig. 7e, f). The linear trends of PRCPTOT in August are predominantly positive throughout the region (Fig. $7 \mathrm{~g}$ ), and significant positive trends appear in the south-central region. In contrast, PRCPTOT is predominantly negative in September (Fig. 7h), and significant negative PRCPTOT trends are typical for $26.32 \%$ of the stations in the southeastern and northeastern areas. For the whole region, PRCPTOT exhibits the most obvious

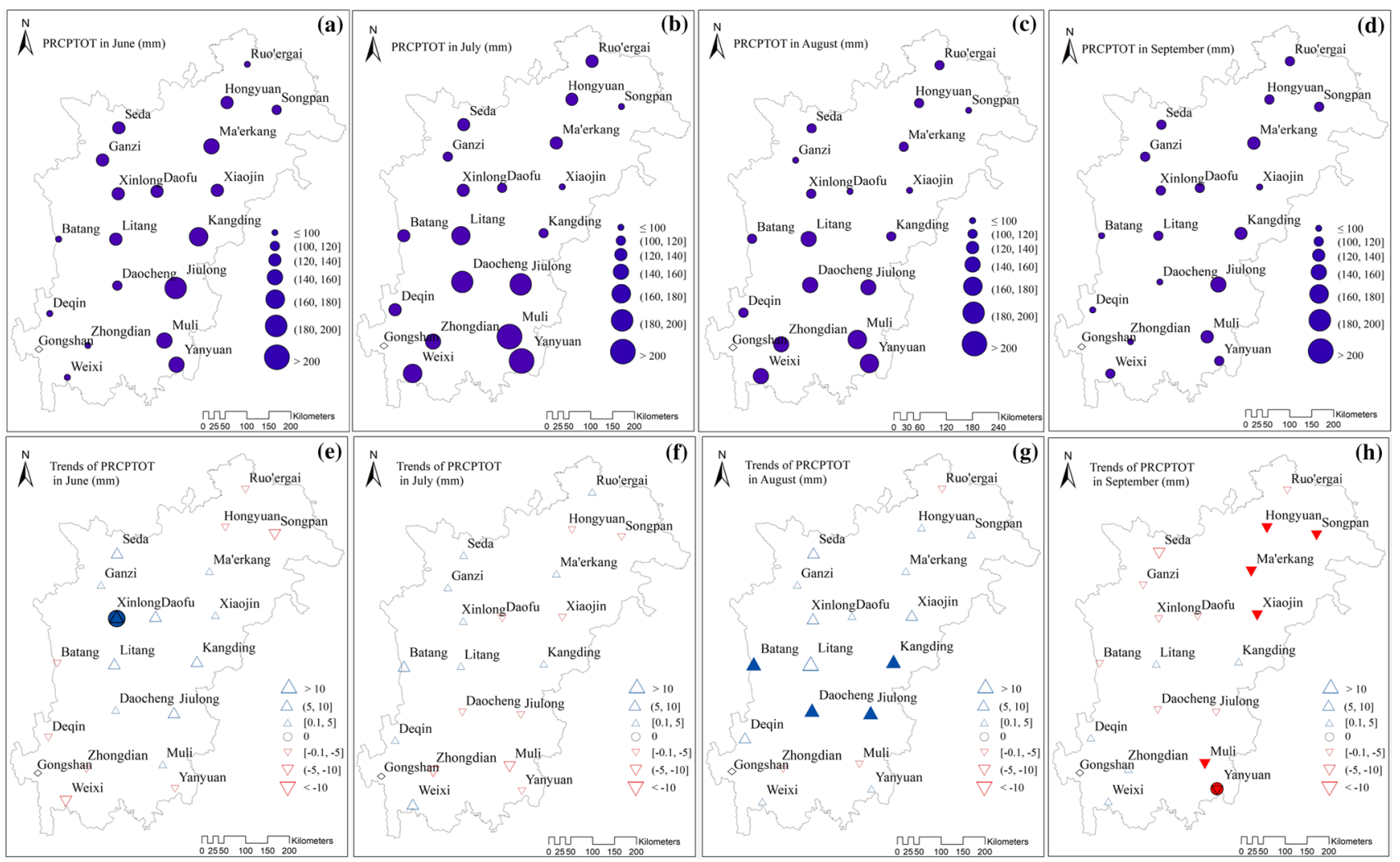

Fig. 7 Monthly spatial distribution of the PRCPTOT characteristics and linear trends (per decade) over the Chuandian Plateau from 1971 to 2015 
increase in August at a rate of $4.95 \mathrm{~mm}$ decade $^{-1}$, but PRCPTOT decreases by $-3.47 \mathrm{~mm}$ decade $^{-1}$ in September, which passes the significance test at the 0.1 level (Table 3). Clearly, the largest values of the PRCPTOT trends are observed in August. This could be an indication that the rainy season has lengthened from 1971 to 2015. In addition, studies have confirmed that since the late 20th century, the SASM and EASM have shown a weakening trend and a consequent reduction in precipitation [35, 38]. This study reflects that this decrease mainly occurs in September.

\subsubsection{SDII index}

The spatial distribution of the monthly SDII index is expressed as the high-value area occupying most of the eastern part of the region with a north to south distribution in June, which then moves to the south and north in July. Later, the high-value area continues to move south and north, and the range decreases. In September, the high-value area is back in the eastern part of the region, but the spatial difference exhibits a noticeable decrease (Fig. 8a-d). From June to September, the spatial differences are reduced, and the CV is $15.89 \%, 14.54 \%, 11.73 \%$ and 8.62 , for June, July, August, and September, respectively.
The largest SDII values in all the months are at the Yanyuan station. The largest average SDII throughout the region occurs in July.

For the monthly SDII, positive trends are found at $68.42 \%, 73.68 \%, 89.47 \%$ and $52.63 \%$ of the stations considered for each month. Thus, there are no obvious spatial distribution patterns (Fig. 8e-h). Approximately, 5.26\%, $15.79 \%, 10.53 \%$ and $5.26 \%$ of the stations indicate significant and strongly significant positive trends in each month. However, there are nonsignificant negative linear trends. For the whole region, the SDII trends are predominantly positive in each month, and the SDII values in August and July exhibit the most obvious increases of $0.22 \mathrm{~mm}$ decade $^{-1}$ and $0.18 \mathrm{~mm}$ decade $^{-1}$, respectively, which pass the significance test at the 0.05 level (Table 3 ).

\subsubsection{RX1 day index}

The spatial distribution for the monthly RX1 day is consistent with the years and seasons; moreover, there is little difference between the months (Fig. 9a-d). In June, the largest spatial difference is found, with a CV of $20.40 \%$. In July, there is a larger average value than that in the other months. The minimum values of RX1 day typically occur at the Deqin station in June and September and at

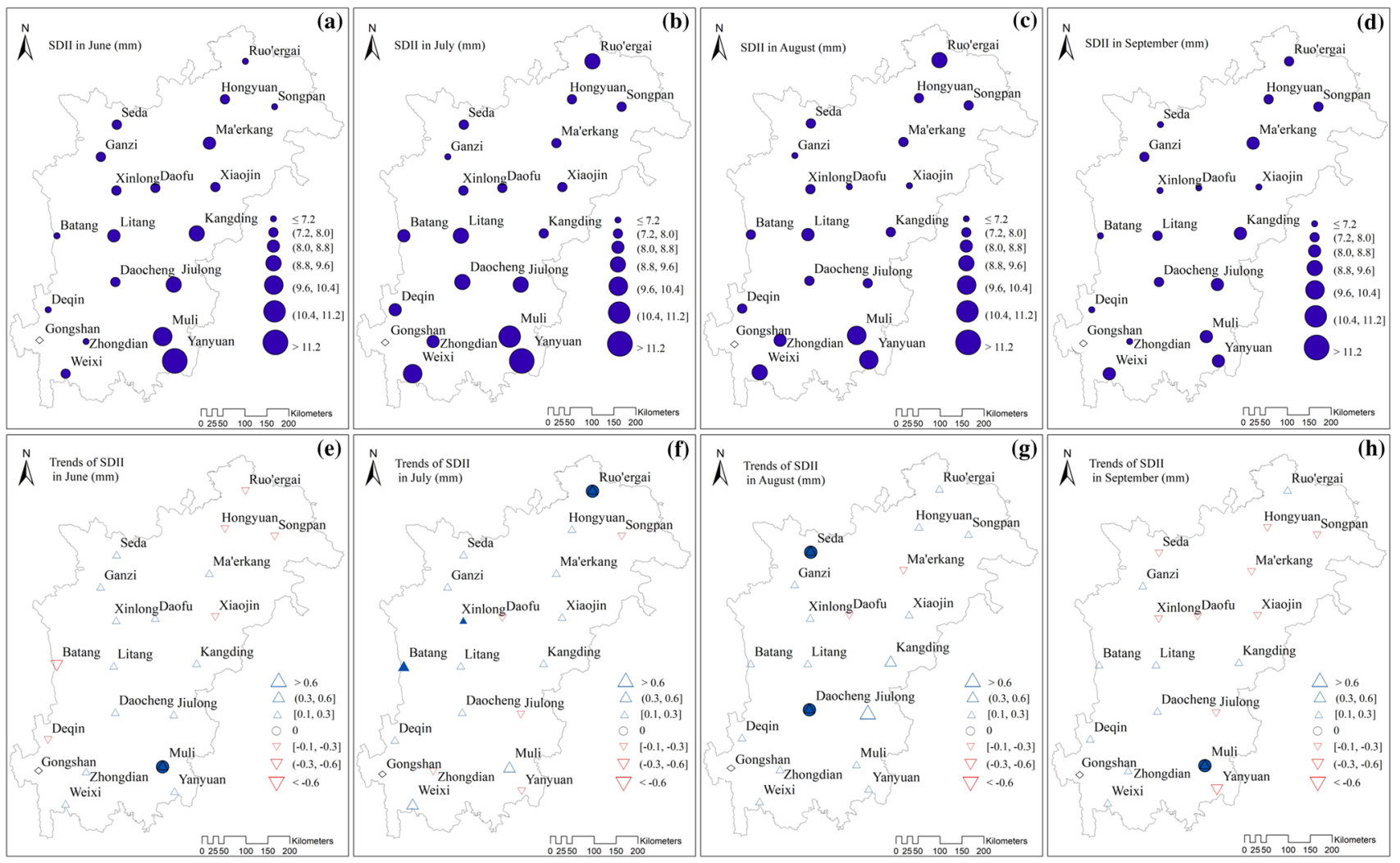

Fig. 8 Monthly spatial distribution of the SDII characteristics and linear trends (per decade) over the Chuandian Plateau from 1971 to 2015 


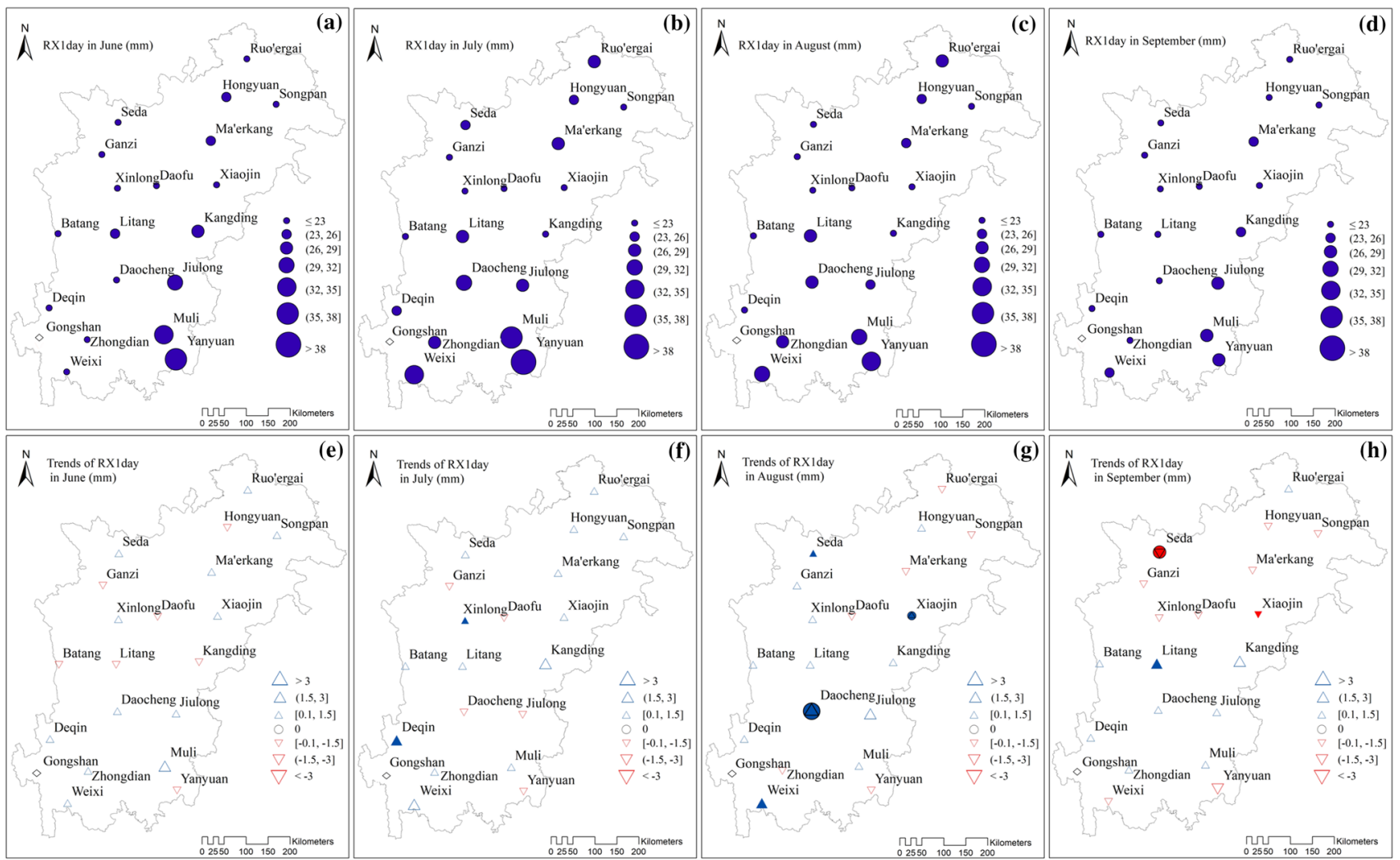

Fig. 9 Monthly spatial distribution of the RX1 day characteristics and linear trends (per decade) over the Chuandian Plateau from 1971 to 2015

the Xiaojin station in July and August. The maximum values of RX1 day typically occur at the Yanyuan station in all months. A large gradient of RX1 day still exists in the southern area.

For the monthly RX1 day, which exhibit no obvious spatial distribution pattern, positive trends are found at $63.16 \%, 73.68 \%, 68.42 \%$ and $47.37 \%$ of the stations considered for June, July, August and September, respectively (Fig. 9e-h). Approximately, $10.53 \%$ and $21.05 \%$ of the stations show significant and strongly significant positive trends in July and August, respectively. However, there are nonsignificant linear trends in June. The trends of RX1 day are predominantly positive over the whole region in June, July and August. The negative trends are mainly observed in September, with $20 \%$ of the stations exhibiting significance and strong significance. For the whole region, the RX1 day in August and July show the most obvious increases of $0.8 \mathrm{~mm}$ decade $^{-1}$ and $0.6 \mathrm{~mm} \mathrm{decade}^{-1}$, which are significant at the 0.05 level (Table 3 ).

\subsubsection{RX5 day index}

The spatial distributions for the monthly RX5 day are consistent among the different years and seasons; moreover, there are few differences between the months (Fig. 10a-d). In June, the CV is $24.93 \%$, which is the largest spatial difference in any of the months. In July, the average value of $59.39 \mathrm{~mm}$ is larger than that in the other months. The minimum RX5 day values typically occur at the Deqin station in June and September and the Xiaojin station in July and August, and these patterns are consistent with those for RX1 day. The maximum RX5 day values typically occur at the Yanyuan station in June and July, the Muli station in August and the Jiulong station in September. A large gradient of RX5 day still exists in the southern area.

For the monthly RX5 day, positive trends are found in $31.58 \%, 68.42 \%, 63.16 \%$ and $47.37 \%$ of the stations considered for each month (Fig. 10e-h). The spatial distribution of RX5 day reveals that most of the downward trends are specific to the southern and northern locations, while the upward trends are more specific to the central areas. However, there are large differences between the months. The trends of RX5 day are predominantly negative, with values of $-0.48 \mathrm{~mm}$ and $-0.07 \mathrm{~mm}$ over the whole region in June and September, respectively. The positive trends of $0.97 \mathrm{~mm}$ and $0.55 \mathrm{~mm}$ are mainly observed in July and August, respectively. 


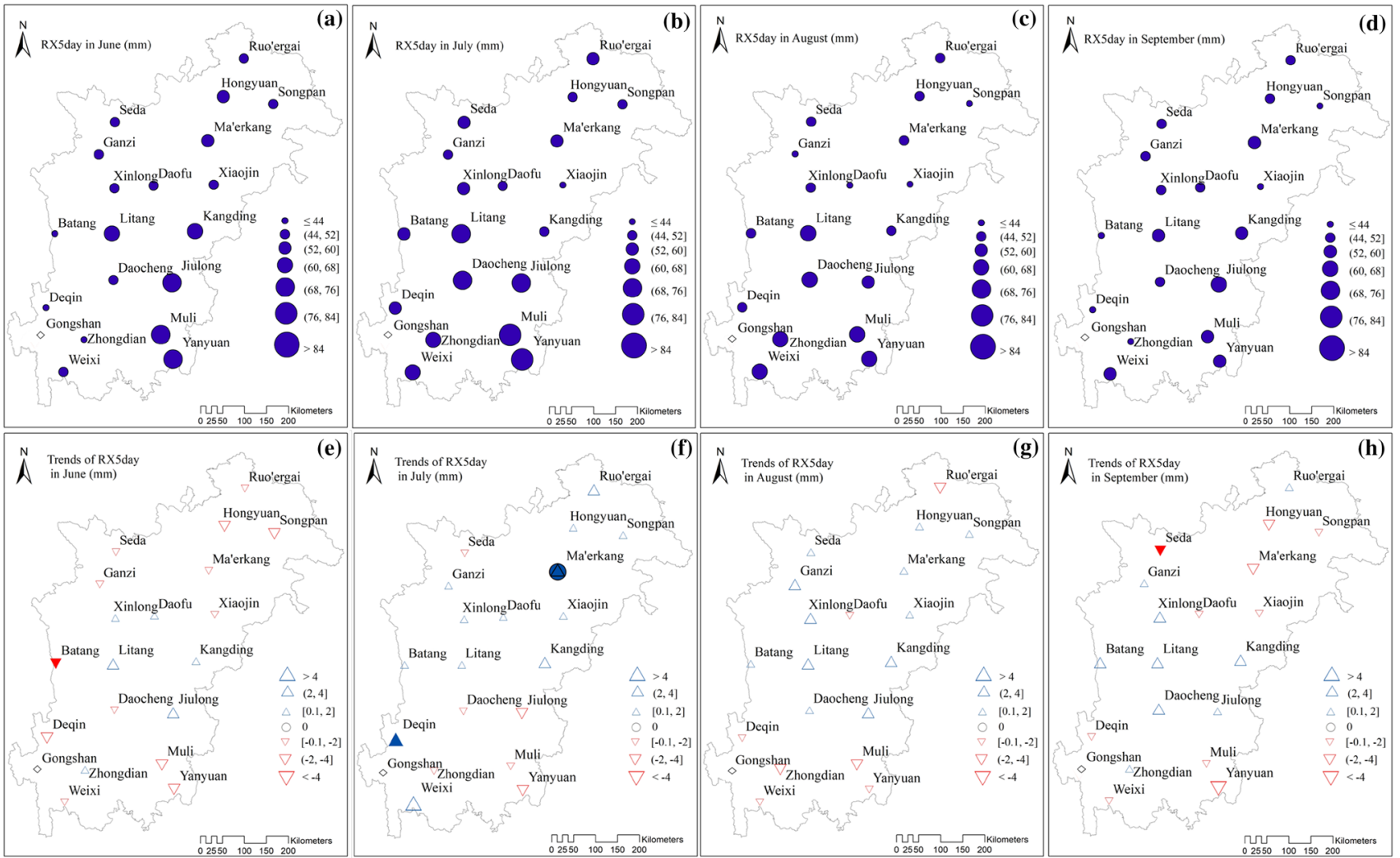

Fig. 10 Monthly spatial distribution of the RX5 day characteristics and linear trends (per decade) over the Chuandian Plateau from 1971 to 2015

\subsubsection{R95pTOT index}

The spatial distribution of the monthly R95pTOT shows that the high-value areas occupy most of the eastern part of the region with a north to south distribution in June. Then, these high values move to the central part of the region, where the largest spatial difference occurs in June. Next, the spatial differences continue decreasing. In September, the high-value areas return to the eastern part of the region, and there is minimal differentiation between stations (Fig. 11a-d). However, the highest average value still occurs in July.

Most of the R95pTOT series is characterized by increasing slopes $(73.68 \%, 78.95 \%$ and $63.16 \%$ of the locations in June, July and August, respectively) except for a decrease in this trend (52.63\% of the locations) in September (Fig. 11e-h). The spatial distribution of the monthly trends is similar to those identified in the different years and seasons: R95pTOT increases by $2.32 \mathrm{~mm}$ decade $^{-1}$ in July, which is similar to the average for the whole region over the period from 1971 to 2015; this pattern is significant at the 0.1 level (Table 3). The R95pTOT values increase in August and June and are lower than those in July. The increasing rate (between 0.8 and $10.59 \mathrm{~mm}^{\text {decade }}{ }^{-1}$ ) varies more than the decreasing rate (between -0.14 and $-4.32 \mathrm{~mm}$ decade $^{-1}$ ) in August. However, there are downward trends of $-0.08 \mathrm{~mm}^{\text {decade }}{ }^{-1}$ in September. For the whole region, a dominant increase is observed in the eastern and central areas, and decreasing trends are observed in the western and northern areas.

It must be noted that June and July are the months with relatively large precipitation (Fig. 1). As expected, the spatial distribution of the average extreme precipitation indices during these months reflects the spatial pattern observed in the wet season. However, the largest trends are observed in July and August, except for that of PRCPTOT (Table 3 ). This could be an indication that the rainy season is lengthening. A similar conclusion has been reached in other areas $[40,41]$.

\subsection{Extreme precipitation intensity analysis at the Gongshan station}

The trends of the extreme precipitation intensity are listed in Table 4. The annual average trends of PRCPTOT, SDII, RX1 day, RX5 day and R95pTOT reached $-40.98 \mathrm{~mm}$ decade $^{-1},-0.1 \mathrm{~mm}$ decade $^{-1},-2.4 \mathrm{~mm}$ decade $^{-1}$, $-3.3 \mathrm{~mm}$ decade $^{-1}$ and $-20.55 \mathrm{~mm}$ decade $^{-1}$, respectively. 


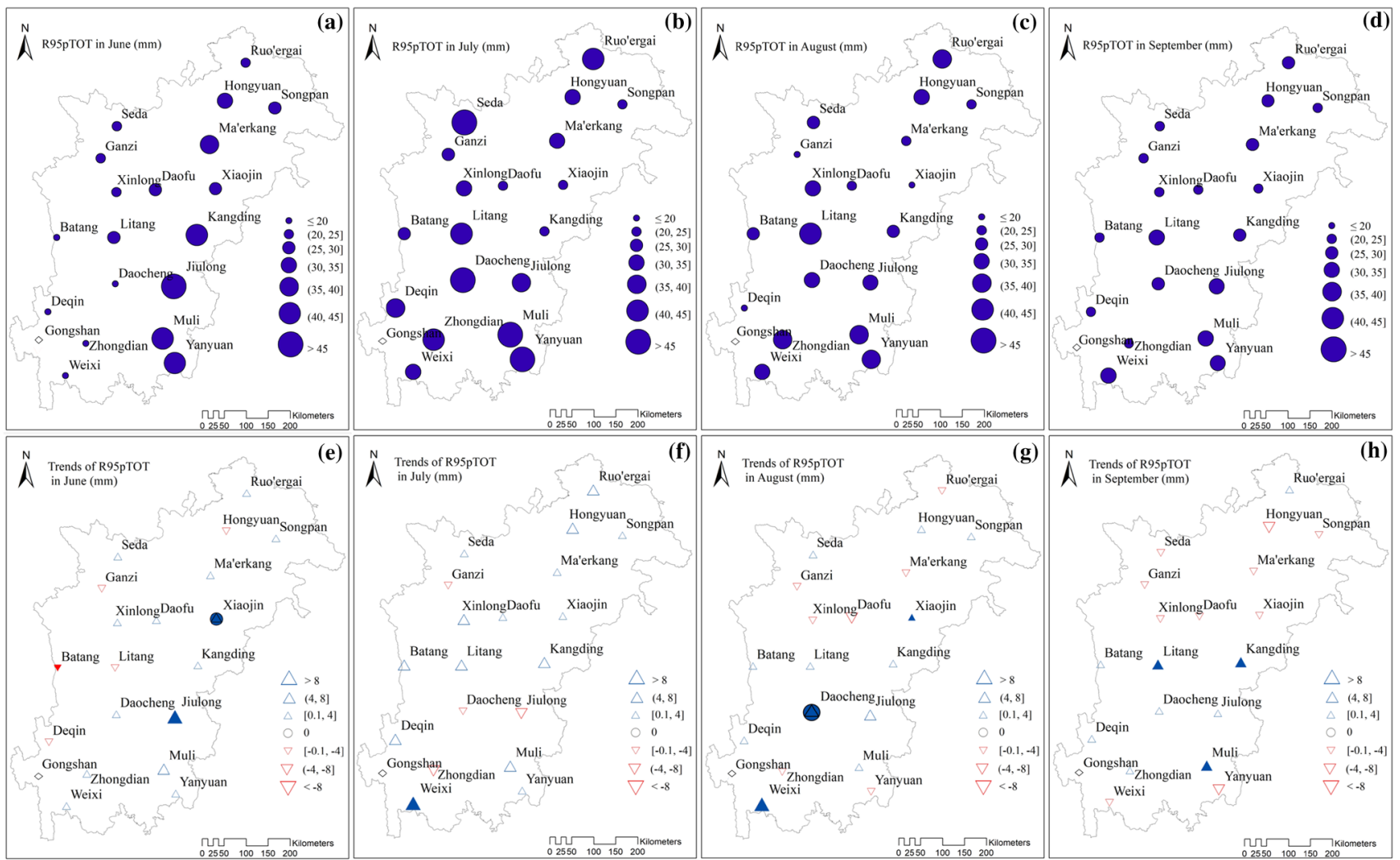

Fig. 11 Monthly spatial distribution of the R95PTOT characteristics and linear trends (per decade) over the Chuandian Plateau from 1971 to 2015

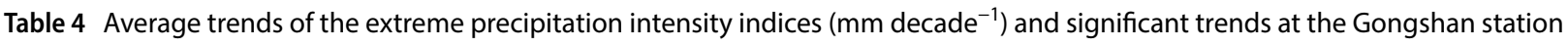

\begin{tabular}{lccccccccccccc}
\hline Indices & Annual & Dry season & Wet season & February & March & April & May & June & July & August & September & October \\
\hline PRCPTOT & -40.98 & -7.62 & -33.36 & -6.93 & -5.62 & -14.74 & 11.89 & -13.34 & -3.05 & 10.77 & -6.27 & -6.07 \\
SDII & -0.1 & 0.23 & -0.13 & -0.24 & -0.14 & -0.72 & 0.76 & -0.5 & -0.07 & $0.44^{*}$ & -0.19 & -0.26 \\
RX1 day & -2.4 & -1.13 & -2.37 & -0.07 & -0.36 & -2.50 & $3.57^{*}$ & -2.59 & 1.65 & 1.50 & -0.71 & -1.50 \\
RX5 day & -3.3 & 1.32 & -3.33 & -1.80 & 2.03 & -7.3 & 5.43 & -4.81 & -0.22 & 2.58 & -4.91 & -4.36 \\
R95pTOT & -20.55 & -3.40 & -16.07 & 2.19 & 0 & $-26.74^{* *}$ & 8.73 & -7.36 & 1.28 & 3.08 & -3.78 & -5.72 \\
\hline
\end{tabular}

${ }^{*}$ At level $a=0.1,{ }^{* *}$ At level $a=0.05$

Of the two seasons, the wet season shows a greater decreasing trend than that of the dry season for all the indices, with average trend values of $-33.36 \mathrm{~mm}$ decade $^{-1}$, $-0.13 \mathrm{~mm}$ decade $^{-1},-2.37 \mathrm{~mm}$ decade $^{-1},-3.33 \mathrm{~mm}$ decade $^{-1}$ and $-16.07 \mathrm{~mm}^{\text {decade }}{ }^{-1}$. Of the 9 months analyzed, April shows the greatest decreasing trend, with an average PRCPTOT trend value of $-14.74 \mathrm{~mm} \mathrm{decade}^{-1}$, an average SDII trend value of $-0.72 \mathrm{~mm}$ decade ${ }^{-1}$, an average RX5 day trend value of $-7.3 \mathrm{~mm}$ decade $^{-1}$ and an average R95PTOT trend value of $-26.74 \mathrm{~mm}_{\text {decade }}{ }^{-1}$. The greatest decreasing trend in RX1 day is observed in June, with an average value of $-2.59 \mathrm{~mm}$ decade $^{-1}$. However, in May, each index is positive, and the maximum values of all the months are observed in May. According to Table 4, $71.67 \%$ of the indices show negative trends, and R95PTOT in April shows a significant decreasing trend at the 0.05 level. SDII in August and RX1 day in May show significant increasing trends at the 0.1 level.

\section{Discussion and conclusions}

\subsection{Discussion}

The changes in the extreme precipitation intensity are compared with those in other regions (Table 5). The annual 
Table 5 Trends of the extreme precipitation intensity from this study and other studies. Data sources: Yunnan Province (Chen et al. [20]), Southwest (Li et al.[14]), China (You et al. [39]), and Global (Alexander et al. [44])

\begin{tabular}{lcclll}
\hline Region & This study & $\begin{array}{l}\text { Yunnan Prov- } \\
\text { ince }\end{array}$ & Southwest & China & Global \\
\hline PRCPTOT & 4.24 & -4.68 & 0.03 & 3.21 & $10.59^{* *}$ \\
SDII & $0.09^{* *}$ & $0.11^{* *}$ & 0.03 & 0.06 & 0.05 \\
RX1 day & 0.26 & 0.47 & $0.05^{* *}$ & 1.37 & $0.85^{* *}$ \\
RX5 day & -0.04 & -0.14 & 0.03 & 1.9 & 0.55 \\
R95pTOT & $4.29^{*}$ & 3.76 & 0.04 & 4.06 & $4.07^{* *}$ \\
\hline
\end{tabular}

*At level $a=0.1,{ }^{* *}$ At level $a=0.05$

PRCPTOT trend value on the Chuandian Plateau is $4.24 \mathrm{~mm}$ decade $^{-1}$, which is less than the global rate of PRCPTOT increase (i.e., $10.59 \mathrm{~mm}$ decade $^{-1}$ ) over the period from 1951 to 2003 . However, this value is higher than the average rates of PRCPTOT increase over the period from 1961 to 2005 in China (i.e., $3.21 \mathrm{~mm}$ decade $^{-1}$ ), the period from 1961 to 2008 in southwestern China (i.e., $0.03 \mathrm{~mm}$ decade ${ }^{-1}$ ) and the period from 1960 to 2013 in Yunnan Province in China (i.e., $-4.68 \mathrm{~mm}$ decade ${ }^{-1}$ ). SDIl shows an increasing trend that is similar to that in other regions, and the magnitude of the trend is greater than that in all the other regions except Yunnan Province, and the RX1 day trend is smaller than that in all other regions except the southwestern region. RX5 day is the only index with a negative trend, which is consistent with the trend of Yunnan Province. The largest positive trend among all the comparable regions on the Chuandian Plateau is found in the R95PTOT index. Generally, for the annual extreme precipitation intensity, the climate of the Chuandian Plateau became wetter over the 45-year period (1971-2015), especially in the central areas. It can be concluded that the precipitation intensity becomes more extreme, indicating consistent trends toward wetter conditions across most of the indices, even though the great majority are not statistically significant.

The precipitation regime on the Chuandian Plateau is highly variable in both space and time, as the topography of the region is highly complex. Table 6 shows that the negative correlation coefficients between the extreme precipitation intensity indices and altitude reached $91.43 \%$ for all the indices, and $62.86 \%$ of the indices passed the significance test. Table 6 also shows that $100 \%$ of the indices show negative correlations between the extreme precipitation intensity indices and latitude, with $71.43 \%$ of the indices passing the significance test. However, the correlation between the extreme precipitation intensity and longitude is not significant, with only $25.71 \%$ of the indices passing the significance test. The study area is located at the intersection of the movement of water vapor from the Indian Ocean and the Pacific Ocean. The contribution rate of water vapor from the Pacific Ocean decreases gradually in the western and northern parts of the region, while the contribution rate of water vapor from the Indian Ocean generally decreases in the eastern and northern parts of the region [42]. In addition, the altitude of the study area

Table 6 Correlation coefficients of the extreme precipitation intensity indices and altitude, latitude and longitude

\begin{tabular}{|c|c|c|c|c|c|c|c|}
\hline Indices & Altitude (m) & Latitude $\left({ }^{\circ} \mathrm{N}\right)$ & Longitude ( $\left.{ }^{\circ} \mathrm{E}\right)$ & Indices & Altitude (m) & Latitude $\left({ }^{\circ} \mathrm{N}\right)$ & Longitude $\left({ }^{\circ} \mathrm{E}\right)$ \\
\hline PRCPTOT & $-0.604^{* *}$ & $-0.395^{*}$ & -0.22 & RX1 day in July & -0.295 & $-0.675^{* *}$ & -0.159 \\
\hline PRCPTOT in wet season & -0.32 & $-0.504^{* *}$ & -0.105 & RX1 day in August & -0.283 & $-0.618^{* *}$ & -0.177 \\
\hline PRCPTOT in dry season & $-0.623^{* *}$ & -0.248 & -0.232 & RX1 day in September & $-0.61^{* *}$ & -0.367 & 0.156 \\
\hline PRCPTOT in June & -0.376 & -0.071 & 0.202 & RX5 day & $-0.568^{* *}$ & $-0.643^{* *}$ & $-0.46^{* *}$ \\
\hline PRCPTOT in July & -0.16 & $-0.727^{* *}$ & -0.343 & RX5 day in wet season & $-0.442^{*}$ & $-0.712^{* *}$ & -0.337 \\
\hline PRCPTOT in August & -0.138 & $-0.762^{* *}$ & $-0.402^{*}$ & RX5 day in dry season & $-0.632^{* *}$ & $-0.463^{* *}$ & $-0.394^{*}$ \\
\hline PRCPTOT in September & $-0.383^{*}$ & -0.029 & 0.243 & RX5 day in June & $-0.497^{* *}$ & -0.325 & 0.026 \\
\hline SDII & $-0.618^{* *}$ & $-0.77^{* *}$ & -0.36 & RX5 day in July & $-0.217^{* *}$ & $-0.729^{* *}$ & -0.307 \\
\hline SDII in wet season & $-0.431^{*}$ & $-0.637^{* *}$ & -0.057 & RX5 day in August & -0.132 & $-0.729^{* *}$ & $-0.446^{* *}$ \\
\hline SDII in dry season & $-0.712^{* *}$ & $-0.568^{* *}$ & $-0.38^{*}$ & RX5 day in September & $-0.527^{* *}$ & $-0.434^{*}$ & -0.064 \\
\hline SDIl in June & $-0.474^{* *}$ & $-0.426^{*}$ & 0.117 & R95рTOT & $-0.611^{* *}$ & $-0.44^{*}$ & -0.264 \\
\hline SDII in July & -0.258 & $-0.682^{* *}$ & -0.165 & R95pTOT in wet season & 0.025 & -0.145 & $0.406^{*}$ \\
\hline SDII in August & -0.196 & $-0.394^{*}$ & 0.061 & R95pTOT in dry season & $-0.612^{* *}$ & -0.376 & $-0.418^{*}$ \\
\hline SDII in September & $-0.623^{* *}$ & $-0.387^{*}$ & 0.111 & R95pTOT in June & -0.341 & -0.023 & $0.477^{* *}$ \\
\hline RX1 day & $-0.605^{* *}$ & $-0.646^{* *}$ & -0.325 & R95pTOT in July & 0.318 & -0.333 & -0.011 \\
\hline RX1 day in wet season & $-0.457^{* *}$ & $-0.627^{* *}$ & -0.095 & R95pTOT in August & 0.221 & -0.291 & 0.064 \\
\hline RX1 day in dry season & $-0.668^{* *}$ & $-0.528^{* *}$ & $-0.401^{*}$ & R95pTOT in September & $-0.552^{* *}$ & $-0.583^{* *}$ & -0.261 \\
\hline RX1 day in June & $-0.534^{* *}$ & $-0.395^{*}$ & 0.156 & & & & \\
\hline
\end{tabular}

*At level $a=0.1,{ }^{* *}$ At level $a=0.05$ 
increases from south to north, the south is dominated by longitudinal mountains and valleys, and the water vapor mainly comes from the Indian Ocean [43]. The north is dominated by a plateau, which is relatively far from the ocean, so it is not easily reached by the water vapor. Therefore, the latitude and altitude magnify the difference in the spatial distribution of the water vapor from the Indian Ocean and the Pacific Ocean in his study area. The existence of clear dry and wet seasons is an important climatic characteristic in the region. In previous studies on precipitation, seasonal time series used the standard season definition: winter (DJF), spring (MAM), summer (JJA) and autumn (SON) $[44,45]$. This definition is based on temperature changes throughout a year. However, precipitation varies from regionally and has large spatial and temporal variability. Therefore, the standard season definition masks the temporal distribution of precipitation in specific areas and cannot be used to accurately identify the dry and wet seasons. In this study, we divide the dry and wet seasons by using $K$-means clustering, and the results are very clear. The wet season includes four continuous months when $67.3 \%$ of the total annual precipitation occurs, and the dry season includes eight months when $32.7 \%$ of the total annual precipitation occurs. This method can better reflect the seasonal concentration of precipitation.

\subsection{Conclusions}

In this work, the annual, seasonal and monthly spatial distribution and trends of the extreme precipitation intensity are evaluated using observations from 20 stations on the Chuandian Plateau from 1971 to 2015, and these trends are tested for statistical significance. Almost all of the stations show consistent characteristics among the five extreme precipitation intensity indices at multiple time scales: (1) The overall characteristic of the spatial difference in the extreme precipitation intensity increases from the north to the south. (2) Due to the influence of monsoons, there are distinct wet and dry seasons in this region. All the indices have larger values and smaller spatial differences during the wet season than those during the dry season. The spatial variability of June and the average values of July are greater than those of the other months in the wet season. (3) The maximum values of the indices throughout the year and during the dry season occur in the southwestern part of the region, and those for the wet season and June to September occur in the southeastern part of the region. The minimum values occur in the western part of the region (including the Batang, Ganzi, Seda and Deqin stations) and the eastern part of the region (Xiaojin station).

At the seasonal scale, the trend rates of each index increase more evidently during the wet season than those throughout the year, except that of PRCPTOT. The values of SDII, RX1 day and R95PTOT during the wet season are significant at the 0.05 level. Both the PRCPTOT and RX5 day trend rates increase from the north and south to the center. SDII, RX1 day and R95pTOT increase faster in the southeastern area than in the other areas. The climatic trends of the extreme precipitation intensity indices during the dry season are all much less than those during the wet season. This is especially true for R95pTOT during the dry season (i.e., $-0.27 \mathrm{~mm}$ decade $\left.^{-1}\right)$, which exhibits the largest difference from the values in the wet season (i.e., $5.87 \mathrm{~mm}$ decade $^{-1}$ ). June and July are the months with relatively large precipitation. However, all the indices of extreme precipitation intensity in July and August show consistently increasing trends, with $50 \%$ of the values passing the significant test, and the largest trends are observed in July and August, except for that of PRCPTOT. This could be an indication that the rainy season is lengthening.

For the entire region, the intensity of the extreme precipitation has a relatively strong trend in the wet season, especially SDII, RX1 day and R95PTOT in July and August, which are the largest contributors to the annual rainfall seasonally and monthly. In addition, the precipitation days in the whole region are decreasing, especially in Muli, Gongshan and Yanyuan, with decreases of -6.62 days decade ${ }^{-1},-6.39$ days decade ${ }^{-1}$ and -6.38 days decade ${ }^{-1}$, respectively. This could be an indication that precipitation is becoming more concentrated and occurring in fewer and more intense events. Thus, very serious problems, such as landslides, mudslides, mountain floods and other geomorphological disasters, will be caused by the increase in the extreme precipitation intensity in the region. This study focuses on the characteristics and trends of the annual, seasonal and monthly extreme precipitation intensity, which is critical for understanding the extreme precipitation intensity-related disasters and developing appropriate adaptation and mitigation strategies. An analysis of the mechanisms that influence the precipitation extremes is planned in future work.

Acknowledgements This study is funded by the Sichuan education department key project (18ZA0275).

Funding This study is funded by the Sichuan education department key project (18ZA0275).

\section{Compliance with ethical standards}

Conflict of interest The authors declare that they have no conflict of interest. 


\section{References}

1. Scherrer SC, Begert M, Croci-Maspoli M, Appenzeller C (2016) Long series of Swiss seasonal precipitation: regionalization, trends and influence of large-scale flow. Int J Climatol 36(11):3673-3689

2. IPCC (2007) Climate change 2007: the physical science basis. Cambridge University Press, Cambridge

3. IPCC (2012) Summary for policymakers. In: Managing the risks of extreme events and disasters to advance climate change adaptation. a special report of working groups I and II of the intergovernmental panel on climate change. Cambridge University Press, Cambridge, UK

4. Min SK, Zhang XB, Zwiers FW, Hegerl GC (2011) Human contribution to more-intense precipitation extremes. Nature 470:378-381

5. Frich P, Alexander LV, Della-Marta P, Gleason B, Haylock M, Tank AMGK, Peterson T (2002) Observed coherent changes in climatic extremes during the second half of the twentieth century. Climate Res 19:193-212

6. Diaz HF, Grosjean M, Graumlich L (2003) Climate variability and change in high elevation regions: past, present and future. Clim Change 59:1-4

7. Zhao P, Yang S, Yu RC (2010) Long-term changes in rainfall over eastern China and large-scale atmospheric circulation associated with recent global warming. J Clim 23:1544-1562

8. Li ZX, He YQ, Wang CF, Wang XF, Xin HJ, Zhang W, Cao WH (2011) Spatial and temporal trends of temperature and precipitation during 1960-2008 at the Hengduan Mountains, China. Quatern Int 236:127-142

9. Wu FF, Wang X, Cai YP, Li CH (2016) Spatiotemporal analysis of precipitation trends under climate change in the upper reach of Mekong River basin. Quatern Int 392:137-146

10. Xiao XY, Shen J, Wang SM, Xiao HF, Tong GB (2010) The variation of the southwest monsoon from the high resolution pollen record in Heqing Basin, Yunnan Province, China for the last 2.78 Ma. Palaeogeogr Palaeoclimatol Palaeoecol 287:45-57

11. Lau KM, Li MT (1984) The monsoon of East-Asia and its global associations-a survey. Bull Am Meteor Soc 65(2):114-125

12. Wang B, Wu RG, Fu XH (2000) Pacific-East Asian teleconnection: how does ENSO affect East Asian climate? J Clim 13(9):1517-1536

13. Deser C, Alexander MA, Xie SP, Phillips AS (2010) Sea surface temperature variability: patterns and mechanisms. Ann Rev Mar Sci 2(1):115-143

14. Li ZX, He YQ, Wang PY, Theakstone WH, An WL, Wang XF, Lu AG, Zhang W, Cao WH (2012) Changes of daily climate extremes in southwestern China during 1961-2008. Glob Planet Change $80-81: 255-272$

15. Yuan WD, Zheng JK, Dong K (2014) Spatial and temporal variation in extreme precipitation events in southwestern China during 1962-2012. Resour Sci 36(4):766-772 (in Chinese)

16. Luo Y, Fan GZ, Zhou DW, Hua W, Li JJ (2015) Extreme precipitation trend of Southwest China in recent 41 years. J the Meteorol Sci 35(5):581-586 (in Chinese)

17. Hu HR, Mao XL, Liang $L$ (2009) Temporal and spatial variations of extreme precipitation events of flood season over sichuan basin in last 50 years. Acta Geogr Sin 64(3):278-288 (in Chinese)

18. Zhang SQ, Ma ZF (2011) Change tendency and cyclicity analysis of extreme precipitation over sichuan province during 1961-2009. J Nat Resour 11:1918-1929 (in Chinese)

19. Sun C, Cheng ZG, Mao XL, Mei SD, Yang XY (2017) Extreme climatic change trend and features in Sichuan for the latest 44 years. J Lanzhou Univ Nat Sci 53(1):119-126 (in Chinese)
20. Chen FL, Chen HM, Yang YY (2015) Annual and seasonal changes in means and extreme events of precipitation and their connection to elevation over Yunnan Province, China. Quatern Int 374:46-61

21. Du HM, Yan JP, Wang PT (2015) The drought disaster and its response to the warming-drying climate in the farming-pastoral ecotones in northern China. J Arid Land Resour Environ 1:124-128 (in Chinese)

22. Zhao W, Wei ZG, Zheng ZY, Dong WJ (2016) Surface temperature and precipitation variation of pastoral transitional zone in Northern China during 1964-2013. Plateau Meteorol 4:979-988 (in Chinese)

23. Li YG, He DM, Hu JM, Cao J (2015) Variability of extreme precipitation over Yunnan Province, China 1960-2012. Int J Climatol 35:245-258

24. Fu X, Kuo CC, Gan TY (2015) Change point analysis of precipitation indices of Western Canada. Int J Climatol 35:2592-2607

25. Ni QS (2007) The application of SPSS experimental course. Hunan University Press, Hunan, pp 171-172 (in Chinese)

26. Hu Q, Pan FF, Pan XB, Li QY, Shao CX, Pan ZH, Wei YR (2016) Trends in agricultural heat and solar radiation resources in Northeast China: a multistage spatio-temporal analysis. Int J Climatol 36:2461-2468

27. Lupikasza EB, Hansel S, Matschullat J (2011) Regional and seasonal variability of extreme precipitation trends in southern Poland and central-eastern Germany 1951-2006. Int J Climatol 31:2249-2271

28. Li XZ, Hao M, Zhao J, Wang Z, Fu W, Liu ZZ (2018) Effect of longterm fertilization on wheat yield under different precipitation patterns. J Appl Ecol 29(10):3237-3244. https://doi.org/10.13287 /j.1001-9332.201810.025

29. Xu JH (2014) Quantitative geography. Higher Education Press, Beijing (in Chinese)

30. Li ZX, He YQ, Xin HJ, Wang CF, Jia WX, Zhang W, Liu J (2015) Spatio-temporal variations of temperature and precipitation in Mts. Hengduan region during 1960-2008. Acta Geogr Sin 65(5):563-579

31. Li J, Zeng Q (2002) A unified monsoon index. Geophys Res Lett 29(8):111-115

32. Li JP, Zeng QC (2003) A unified monsoon index. Geophys Res Lett 29(8):1151-1154

33. Li JP, Zeng QC (2003) A new monsoon index and the geographical distribution of the global monsoons. Adv Atmos Sci 20(2):299-302

34. Wang B, Ding Q (2006) Changes in global monsoon precipitation over the past 56 years. Geophys Res Lett 33(6):272-288

35. Wang $\mathrm{H}$ (2001) The Weakening of the Asian monsoon circulation after the end of 1970's. Adv Atmos Sci 18(3):376-386

36. Yang XL, Zhang PZ, Chen FH et al (2007) Modern stalagmite oxygen isotopic composition and its implications of climatic change from a high- elevation cave in the eastern Qinghai-Tibet Plateau over the past 50 years. Sci Bull 52(9):1238-1247

37. Zong BY, Li XL, Kathayat G et al (2017) Asian monsoon variability on multiple timescales in the context of global climate changes. $J$ Earth Environ 8(3):185-193 (in Chinese)

38. Yu R, Wang B, Zhou T (2004) Tropospheric cooling and summer monsoon weakening trend over East Asia. Geophys Res Lett 31:L22212. https://doi.org/10.1029/2004GL021270

39. You QL, Kang SC, Aguilar E, Pepin N, Fludel W-A, Yan YP, Xu YM, Zhang YJ, Huang J (2010) Changes in daily climate extremes in China and their connection to the large scale atmospheric circulation during 1961-2003. Clim Dyn 36:2399-2417

40. Biasutti M, Sobel AH (2009) Delayed Sahel rainfall and global seasonal cycle in a warmer climate. Geophys Res Lett 36:L23707

41. Song FF, Leung LR, Lu J, Dong L (2018) Seasonally dependent responses of subtropical highs and tropical rainfall to 
anthropogenic warming. Nat Clim Change 8:787-792. https:// doi.org/10.1038/s41558-018-0244-4

42. Zhou Y, Lu XX, Xu JC (2011) Climate change impact assessment report of yunnan province. Meteorological Press, Beijing (in Chinese)

43. Wang XP, Wang ZH, Fang JY (2004) Mountain ranges and peaks in China. Biodivers Sci 1:206-212 (in Chinese)

44. Alexander LV, Zhang X, Peterson TC, Caesar J, Gleason B, Tank AMGK, Haylock M, Collins D, Trewin B, Rahimzadeh F, Tagipour A, Kumar KR, Revadekar J, Griffiths G, Vincent L, Stephenson DB, Burn J, Aguilar E, Brunet M, Taylor M, New M, Zhai P, Rusticucci M, Vazquez-Aguirre JL (2006) Global observed changes in daily climate extremes of temperature and precipitation. J Geophys Res Atmos 111:D05109. https://doi.org/10.1029/2005JD006290

45. Carvalho MJ, Marta-Almeida M, Melo-Goncalves $P$, Rocha A (2016) Recent trends of extreme precipitation indices in the Iberian Peninsula using observations and WRF model results. Phys Chem Earth 95:10-21

Publisher's Note Springer Nature remains neutral with regard to jurisdictional claims in published maps and institutional affiliations. 